\title{
Family socio-economic status and its influences on adolescents perception of, and attitude to, HIV/AIDS prevention among secondary schools in Cross River State, Nigeria
}

\author{
Akpama $^{12}$, E. G. \& Ekefre $^{13}$, E. N.
}

\begin{abstract}
This study examined the influence of family socio-economic status on adolescent's perception of and attitude to HIV/AIDS preventive measures. The study utilized 900 adolescents (450 males and 450 females) as the population of study. A 20 item questionnaire was used for data collection. One research question guided the study, while one hypothesis was tested. Data collected were analyzed and tested for significance, using a one-way analysis of variance test statistics. The finding revealed that parents' socioeconomic background has no significant influence on adolescents' perception of and attitude to HIV/AIDS prevention. Some recommendations were made as the way forward.
\end{abstract}

Keywords adolescent's attitude, adolescent's perception, family socio-economic status, HIV/AIDS preventive measures,

\section{Introduction}

HIV/AIDS has found ways to protect itself from the Human Immune System. Attempts to control the virus through antibodies or by boosting the body Immune System has failed. Scientists are now turning to novel techniques such as gene and stem cell, though still in their infancy (Baltimore 2008). From various studies, adolescents are well informed and quite knowledgeable about HIV/AIDS transmission and its preventive measures. Adolescents are also quite aware of the dangers of unprotected sex. Yet their knowledge has not prevented them from engaging in unprotected sex. The result of which is the continuous increase in the spread of HIV/AIDS (Oshotimehim, 2003; Olayinka \& Osho, 1997).

Adolescent's perception and attitude towards societal issues such as HIV/AIDS is influenced by the socio-economic background of any family. The first essential mental health for adolescents is the security in the parental relationship derived from parent's affection, care of the adolescents. Parents are the principal correlates of adolescents. They respond to adolescent's needs and wants more than any other group of people (Akpede 2003, Agi, 1999).

Adolescents from different socio-economic background manifest differently in their perception and attitude towards similar social and mental problems whereas most adolescents from high socio-economic background will always want to maintain such status by guarding against anything that many bring disgrace to their parents. Some adolescents from lowincome family background would do anything seemingly possible to crave high status for themselves. On the other hand, there are some adolescents from high socio-economic background whose needs are not met by their parents as result of their parent's ideological view about life. Such adolescents would do anything possible to live up to the economic status of their parents. Nevertheless, there are some adolescents from low income family

12 Dr. Elizabeth G. Akpama is a lecturer in the Department of Educational Foundations, Guidance and Counselling, Cross River University of Technology, Calabar.

$13 \mathrm{Mr}$. Ekeng Nyong Ekefre is a lecturer in the Department of Educational Foundations, Guidance and Counselling, Cross River University of Technology, Calabar. 
Family socio-economic status and its influences on adolescents perception of, and attitude to, HIVIAIDS prevention among secondary schools in Cross River State, Nigeria Akpama, E. G. \& Ekefre, E. N.

would rather see it as a challenge to work hard in their areas of endeavour in order to change their family status (Denga 2002, Akpama 2007, Hodges 2001). These accounts for the positive and negative attitude and perception of adolescents to wards HIV/AIDS prevention.

Although, social rules and prohibitions regulates individuals' nature, it is not only how much wealth a family has that determines the healthy personality of the adolescents. UNAID 2002, Alachi \& Odey 2001, both discovered that economically disadvantaged adolescents are proned to ignore the dangers of unprotected sex by engaging in high risk sex behaviour in order to satisfy their societal demands. Does adolescents perception of and attitude to HIV/AIDS prevention actually being influenced by their parents socio-economic status? This is the crux of this study.

\section{The Problem}

Attempts to eradicate the dreaded disease HIV/AIDS, over the years has proved abortive. Huge financial expenditure by government and non governmental organizations to combat HIV/AIDS has also proved abortive. Health workers and researchers have concentrated on their quest for curative remedy, yet not much has been achieved. There has also been much sensitization on the acquisition, spread and preventive measures yet the dreaded disease still finds ways to protect itself from the human Immune System. The future of Cross River State and indeed Nigeria lies in the hands of the virile adolescents who are being drained away by HIV/AIDS. Studies had been carried out on adolescent's perception and attitude to HIV/AIDS, yet not much has been said and done about the factors that trigger adolescents perception and attitude to HIV/AIDS such as parents socio-economic status.

\section{Purpose of the study and research question}

This study whose scope covers all the eighteen (18) Local Government Areas of Cross River State, Nigeria, was designed to focus on the influence of parents socio-economic status on adolescents perception of and attitude to HIV/AIDS prevention. It was also designed to investigate and ascertain whether a relationship exists between adolescent's perception of and attitude to HIV/AIDS preventive measures and their parent's socio-economic status. The question formulated to guide the study was 'Is there any significant relationship between parent's socio-economic status and adolescent's perception of and attitude to HIV/AIDS preventive measures?'

\section{Methods}

Ex-post facto research design was adopted for this study. The choice was based on the fact that the events had already been identified as having taken place. The information needed for this study already existed in its natural state and was obtained though the use of questionnaire for the evaluation purpose. The proportionate and stratified simple random technique were adopted to ensure equal representation of the groups and to give each school and each student an equal chance of being selected for the study.

The study was carried out among senior student (SS 3) in 293 public schools with a population of 12,846 senior secondary school students in the eighteen (18) local government areas of Cross River State. The 18 Local government areas were stratified into 3 geopolitical zones (north, central and south). The 293 secondary schools were stratified first into the three geopolitical zones and secondly, secondary schools within the local governments within each of the three zones, and thirdly, based on location (urban/rural). The students were also stratified into (boys/girls). Based on the technique, 300 students (150 boys and 150 girls) were selected from 30 selected schools in each of the 3 zones. A total of 900 respondents (450 boys and 450 girls) from 90 sampled schools from the 3 zones were used for the study. 
The instrument used for this study was a 20 - item questionnaire made up of 2. Sections Section "A" sought information on the personal data of the respondents. Section B comprised 20 items arranged in A, B, C and D. A 4 point likert scale ranging from strongly Agreed "SA" (4 points), Agreed "A" (3 points), Disagreed "D" (2 points), and strongly Disagreed "SD" (1 point) was provided for respondents to make their responses to the questionnaire. A pilot study carried out to determine the validity of the instrument yield a coefficient of internal validity of 0.76 . This ascertained the reliability of the instrument. The copies of the questionnaire were administered in the sampled schools by the researcher and 5 research assistants. Mean score and standard deviations were used in answering the research question while a one way analysis of variance was used to test the null hypothesis at 0.05 level of significance.

\section{Findings and Discussions}

The results showing the descriptive statistics on the influence of parents' socio-economic status on adolescents' perception of and attitude to HIV/AIDS preventive measures as well as the test of the null hypothesis that 'there is no significant relationship between parents' socioeconomic status and adolescents' perception of and attitude to HIV/AIDS preventive measures' are presented in Tables 1 and 2.

Table 1 Descriptive statistics on the influence of parents' socio-economic status on adolescents' perception of and attitude to HIV/AIDS preventive measures

\begin{tabular}{lllccc}
\hline Variables & & $\begin{array}{l}\text { Parents } \\
\text { status }\end{array}$ & Socio-economic & & \\
& & & N & $\overline{\boldsymbol{x}}$ & SD \\
\hline Perception & \multirow{2}{*}{ of } & Low & 312 & 22.12 & 7.71 \\
HIV/AIDS & & Average & 284 & 22.75 & 5.84 \\
prevention & & High & 304 & 22.88 & 6.93 \\
& & Total & $\mathbf{9 0 0}$ & $\mathbf{2 2 . 5 7}$ & $\mathbf{6 . 9 0}$ \\
& & & & & \\
Attitude & to & Low & 312 & 25.44 & 6.92 \\
HIV/AIDS & & Average & 284 & 24.66 & 6.20 \\
prevention & & High & 304 & 25.92 & 6.86 \\
& & Total & $\mathbf{9 0 0}$ & $\mathbf{2 5 . 3 6}$ & $\mathbf{6 . 9 6}$ \\
\hline
\end{tabular}


Family socio-economic status and its influences on adolescents perception of, and attitude to, HIV/AIDS

prevention among secondary schools in Cross River State, Nigeria Akpama, E. G. \& Ekefre, E. N.

Table 2 One way analysis of variance of the influence of parents' socio-economic status on adolescents' perception of and attitude to HIV/AIDS preventive measures

\begin{tabular}{|c|c|c|c|c|c|}
\hline Variables & $\begin{array}{l}\text { Source of } \\
\text { variation }\end{array}$ & Sum of square & df & MS & $\mathbf{F}$ \\
\hline \multirow{3}{*}{$\begin{array}{l}\text { Perception } \\
\text { HIV/AIDS } \\
\text { prevention }\end{array}$} & Between & 101.917 & 2 & 50.958 & \\
\hline & Within & 42682.096 & 897 & 47.583 & 0.343 \\
\hline & Total & 42784.013 & 899 & & \\
\hline \multirow{3}{*}{$\begin{array}{l}\text { Attitude } \\
\text { HIV/AIDS } \\
\text { prevention }\end{array}$} & Between & 235.850 & 2 & 117.925 & \\
\hline & Within & 40030.375 & 897 & 44.627 & 2.642 \\
\hline & Total & 40266.223 & 899 & & \\
\hline
\end{tabular}

* Significant at .05; $\mathrm{df}=2$ and 897 ; critical $\mathrm{f}=4.610$

The result of the analysis in Table 2 shows that the critical $\mathrm{f}$ - ratio of 0.343 and 2.642 for perception of and attitude to HIV/AIDS prevention were lower than the critical value of 4.610 at 0.05 level of significance with 2 and 897 degrees of freedom.

The result of this study implies that parent's socio-economic status does not significantly influence adolescent's perception of and attitude to HIV/AIDS prevention. These findings supported (Denga 2002, Akpama 2007, \& Hodges 2001) assertion that adolescents from high. Socio-economic background would rather maintain their status among their peers, while adolescents from low income families would want to crave high status for themselves as a result of peer influence. In line with their findings, adolescents perception of and attitude to HIV/AIDS preventive measures is influenced by peer group rather than by parents socioeconomic influence.

The findings of this study contradicts the earlier finding of Alachi and Odey 2001, UNAIDS 2002 who discovered that the spread of HIV/AIDS among adolescents was closely linked with their parents socio-economic background. They also discovered that economically disadvantaged adolescents are prone to ignore the dangers of unprotected sex in order to alleviate their family status from poor economic status to a higher one.

\section{Conclusion}

From the findings of this study, adolescents perception of and attitude to HIV/AIDS is not significantly influenced by parents' socio-economic status. The study showed that all hands should be put on deck to check the increasing spread of HIV/AIDS among adolescents. An implementation of the stated recommendations will help reconcile the adolescent's perception of and attitude to HIV/AIDS preventive measures. It will also help to cut down drastically, the spread of HIV/AIDS.

\section{Recommendations}

Based on the findings of this study which showed that there is no significant influence of parent's socio-economic status on adolescent's perception of and attitude to HIV/AIDS prevention, this study recommends the following:

- The programmes organized by school counselors and other NGOs on HIV/AIDS should be made to run from time to time and the adolescents (both male and female) should be encouraged to participate effectively. 
- Even though the findings of this study exonerates family socio-economic status, parents still have a role to play in curbing the spread of HIV/AIDS. Parents should maintain good family relationship by supplying adolescents with their needs and also play counseling role to their children at home.

- The task of bringing up children does not rest with parents alone. Since adolescents do not spend all their time at home with parents; government should through its agencies such as the school, religious groups, help parents by teaching acceptable societal values to adolescents.

\section{References}

Agi, G. (1991) Risks and Realities of Early Child Bearing World Wide. New York: Alan Guttmachier Inst.

Akpama, E. G. (2007) Perception and Attitude to HIV/AIDS Prevention among Adolescents in Cross River State. Unpublished Ph.D Thesis, University of Calabar.

Akpede, M. O. (2003) Socio-Demographic Factors in the Perception of HIV/AIDS by Teachers. Unpublished M.Ed Thesis, Ambrose Ali University Ekpoma.

Alachi, J. A., Odey, I.E. (2001) Participatory Family Living: A Recipe for HIV/AIDS Education. Makurdi: Onaivi Press.

Baltimore, D. (2008) American Association for Advanced Science (AAAS). News Paper Publication Independent Daily, Feb. $17^{\text {th }}$.

Denga, D. I. (2002) Educational Psychology ( $2^{\text {nd }}$ Ed.) Calabar: Clearline Publications.

Hodges, A. (2001) Childrens' and Womens' Rights in Nigeria: A Wake-up Call. National Planning Commission Abuja.

Olayinka, B. A.; \& Osho, A. A. (1997) Changes in Attitude Sexual Behaviour and the risk of HIV/AIDS Transmission in South West Africa. East African Medical Journal.

Oshotimehim, I. E., (2003) Preventive Behaviour Education among School Adolescents. Nigerian School of Health. 14(4), 50 - 58.

UNAIDS (2002) AIDS Epidemic Up-Date-Joint United Nations programme on HIV/AIDS. 
